\title{
Political Corruption and Economic Growth in Nigeria
}

\author{
Professor Oguonu Chika Njideka
}

Department of Public Administration, University of Nigeria Nsukka

\section{Dr. Ezeibe Christian Chukwuebuka}

Department of Political Science, University of Nigeria Nsukka

\section{Doi:10.5901/mjss.2014.v5n27p69}

\begin{abstract}
Contrary to the Western liberal school that argued that corruption is a product of moral laxity or decadence; lack of common standard of morality, growing cultural and religious decay, we posit that the root of corruption should not be sought in the value and attitude of individuals in the society rather in the nature of social relations of production. Despite the efforts by political leaderships to evolve anti- corruption strategies, agencies and programmes in Nigeria especially under President Olusegun Obasanjo (1999-2007), the incidence of corruption remains the major enemy of economic growth. Owners of capital and investors consider the Nigerian economy as unsafe for investment due to the prevalence of corrupt political leaderships. In this paper, we explore the impact of political corruption on economic growth in Nigeria since the return of democratic government in 1999. Data was collected largely from documented evidence and analyzed with qualitative descriptive method.
\end{abstract}

Keywords: Corruption, economic growth, development, democracy

\section{Introduction}

One unique feature of liberal democracy is its interconnectedness with economic growth. Democracy allows the people to be actively involved in initiating and improving their standard of living through elections. Arguably, the pervasiveness of democracy in Western Europe and North America generated the large pool of wealth that these regions possessed since the $20^{\text {th }}$ century. Interestingly, leaders of thought in IMF, World Bank and World Trade Organization who are largely influenced by the social sciences that democracy leads to development insist that to be democratic in principles and structure is the basic minimum requirement for loan and economic assistance to developing countries including Nigeria.

Notably, Nigeria which has a population of over 140 million NPC (2006) is endowed with abundant human and natural resources, especially crude oil. In fact, Nigeria's economy is entirely dependent on oil exploration and export. Despite the broad human and natural wealth, "extreme poverty-defined by World Bank as living below \$I per day, corruption, global fluctuation of oil price and policy inconsistency have left Nigeria in a development trap" (ICG, 2006:1). General Yakubu Gowon in 1966 noted that Nigeria suffer want amidst plenty as most people are poorer today than they were in 1960.

However, one of the fundamental objectives of the Nigerian state as provided by the 1999 Constitution of the Federal Republic of Nigeria is to control the national economy in such a manner as to secure the maximum welfare, freedom and happiness of every citizen on the basis of social justice, equality of status and opportunity.

Despite this invaluable objective of the Nigerian state, virtually every sectors of the economy face peculiar challenges. Ofoegbu (1999:112-113) noted that:

Technical problems: Existence of old fashioned equipments and irregular supply of work material reduce the proficiency of the corporations; Financial Problem: Poor financial subvention from government and mismanagement of funds by the management reduce the efficacy of the corporations...Staffing: The corporations are often over-staffed or understaffed; Maintenance Culture: Lack of maintenance of the equipments leads to losses and reduction in the efficiency of the corporations; Political Intervention: Political control and intervention in appointments and award of contracts based on nepotism affect the work of the corporations; Bribery and Corruption: These greatly affect the procedures of work as funds meant for work were either embezzled or misappropriated; Expertise and Experience: Most of the time expertise and ignored and these result in poor performance and or inefficiency...

Ofoegbu ( 1999) remarked that the most politically and economically damaging is the problem of corruption. Corruption presupposes that "firstly, there is a given standard or blueprint of behaviour expected from a public office 
holder and secondly, the pervasion or abandonment of these standards constitutes corruption" (Chuta: 2004:2-3). Similarly, Transparency International continues to rank Nigeria as either the most corrupt, $2^{\text {nd }}$ or $3^{\text {rd }}$ most corrupt in globally especially since the return of democracy in 1999. Other critics observed that Nigeria's liberal democratic agenda is merely targeted at allowing the developed western states access to oil in the Niger Delta in collaboration with the local petit bourgeoisie in Nigeria who collect bribe or tip or as the case may be at the detriment of the Nigerian public.

This paper explores the impact of political corruption on democracy and economic growth in Nigeria. Democracy as a qualitative variable is difficult to measure in quantitative terms. Therefore, we examined the levels of government spending on social and economic services (SES), for the years under study. This is because a democratic regime is likely to spend more money in the provision of these services than military regime. In this paper we also recognized the difficulty in the measurement of corruption. However, we adopt the Corruption Perception Index (CPI) published annually by the Transparency International (TI) on Nigeria and other countries in the world from 1996 to 2010. The index relates the perceptions business people as to the degree corruption. A value of CPI of 10.00 depicts a perfect case totally corruption-free country while a value of 0.00 shows an extreme case of a highly corrupt country. The figures used in the ranking covered the period from 1996 to 2010.

\section{Overview of Corruption in Nigeria}

Most often, Western liberal scholars argued that corruption is a product of moral laxity or decadence; lack of common standard of morality, growing cultural and religious decay. Nokin (1982) believes that corruption emanates from bankrupt and redundant social values whether modern or tradition. Contrarily, the Marxian political economists contend that the root of corruption should not be sought in the value and attitude of individuals in the society rather it should be sought in the nature of social relations of production. In other words, corruption is a product of unequal treatment of things that were once equal in the purest state of man. Central to the dominant capitalist ideology is private accumulation of wealth as the highest form of human activity. Corruption has thus become synonymous with capitalism since every human activity is measured in material acquisitions. Corruption is essentially a structural problem which is derived from and has its existence in the socio-political and economic organization of the society.

The rampant cases of corruption in Nigeria are beyond the issue of ethnicity and morality. It instead resulted from peculiar nature of the social system. In other words, the neo-colonial and dependent capitalist nature of the Nigerian state has made it, and its apparatus serve as vehicles for mindless looting and primitive accumulation of wealth. It is this role of the neo-colonial state that Ekekwe (1986) distinguished from other states in the advanced capitalist countries.

In Nigeria, corruption takes various forms including bribery, favouritism, godfatherism as well as electoral and financial fraud. Corruption has numerous dimensions which include outright embezzlement of funds from the public institutions and solicitation and acceptance of bribes from individuals seeking services provided by the public from those who administers these services. These corrupt practices have registered the vexed question of ideological fraud on the part of our political elites. It also has affected the psyche of the Nigerian youths. Most youths now yearn for capitalist moral ideas and attitudes that belong to the particular group, as material acquisition has become the yardstick for measuring success. This has concomitantly breed an increase in social ills associated with the 'sharp sharp riches' syndrome such as armed robbery, drug/human trafficking, advanced free fraud, popularly referred to as (419), prostitution, kidnapping and terrorism.

In every society, public enterprises are generally recognized as instruments for rapid economic development. Specifically, these enterprises are established to achieve the dual purpose of making profits and achieving other societal objectives such as creating employment and eliminating or reducing mass poverty. Despite these expectations, state enterprises in Nigeria have constantly sent out dangerous signals of inefficiency, official corruption and poor maintenance culture. Consequently, public and most private sectors in Nigeria have not been able to accomplish the noble objectives for which they were established.

Historically, Chuta (2004:17) observed that "corruption as it is known today was unknown in the pre-colonial Nigeria". According to him colonialism brought into Africa various radical changes following education, new religions, urbanization and monetization. Ozoemene Nsugbe a famous local musician noted in his album 'Uka and Omenani' that religion and colonialism introduced bribery and corruption in Nigeria. That British education multiplied evils in Nigeria. According to the musician, embezzlement, bribery, corruption, hoarding, profiting, break and enter, pick pocket, burglary were generally known as evils in Nigeria. In pre-colonial era these evils attracted immediate punishment from the gods and it serves as a form of deterrence for others but after the new religious destroyed the traditions, these evils began to thrive like never before.

In 1960, ethnic politics became entrenched and public office holders were immersed in embezzlement and rigging 
of election. In 1965, "politics had earned universal contempt for their corruption profligacy and indifference attitude towards the interest of the ruled" (Crowther, 1962:266). The raging violence in all parts of the country as a result of state sponsored pervasion of electoral process and administration created an enabling environment for the militarization of the country's political life. According to Major Chukwuma Nzeogwu on January 15 1966, Nigeria's enemies are political profiteers, swindlers, those in different levels of government who subtly use divide and rule policy to keep the people permanently in a situation that will enable and encourage tribalism, nepotistic and make the country 'big for noting' before the international community. They corrupted the society and put the Nigeria political calendar backward by words and deeds and have provided the basics matrix upon which other faulty structures developed.

Major General Aguiyi Ironsi never made any appreciable impact before General Gowon took over in July 1966. General Gowon's era (1966-1975) had unique characteristics. Apart from being a period the country witnessed an unprecedented oil boom and the irregular inflow of petrodollars, it fought a fratricidal war, which almost reduced the country to the shreds and about a million people were killed (Chuta, 2004). The Gowon's regime laid a firm foundation for graft, corruption and shameless embezzlement of funds in Nigeria.

In rationalizing the removal of Gowon, General Murtala Mohammed stated that the nation had been groping in the dark and this situation would inevitably result in fruitless class struggle and bloodshed, indecision, indiscipline and even neglects which characterized the state of affairs under Gowon. To give the nation new lease of life, the Murtala group ousted Gowon. After the bloodshed of Murtala, Major General Olusegun Obasanjo took over. The return of democracy in 1979 under Alhaji Shehu Shagari demonstrated the highest level of pervasion of standards and shameless looting of public fund for personal gains. The extent of professionalization of corruption under the regimes of Generals Ibrahin Babangida and Sani Abacha were also unprecedented. As General Abdulsalami Abubarka replaced Abacha, the rotten 'status quo' was maintained. The regime revealed the looting record of his predecessors but he was also guilty of the same corrupt acts. In line with the tradition of successive military leaders in Nigeria, General Abdusalami set up the Independent National Electoral Commission (INEC) and spent about N4 billion within ten months on INEC. The hosting of the 1999 World Youth Championship by FIFA in Nigeria gulped another N20b and the National Electric Power Authority got N325m for rehabilitation. All these reduced the foreign reserve from about $\$ 76 \mathrm{~b}$ to nearly nothing within ten months. The spending spread became so egregious that it appears nobody was in charge. This was why the National Economic Intelligence Committee discovered that about $\$ 50 \mathrm{~m}$ was missing from the national treasury (Tempo magazine, 1999). As soon as poverty strikes and hunger grasp managers of state apparatus, wealth accumulation became their primary concern. To do otherwise is to be crazy and foolish. The number of unemployed people increased form 1.3m in 1997 to 4.75m in December 1995 and this figure increases annually. All these reinforced social vices thus thuggery, armed robbery, extreme marginalization and youth restiveness.

There was no President or Head of State that carried out strong campaign against corruption in Nigeria like Chief Olusegun Obasanjo. This is because of the global ranking of Nigeria by the Transparency International (TI) in 1998. Despite these efforts the TI report from 1999 to 2010 (mainly under Predident Obasanjo's administration, 1999-2007) was nothing to write home about (See tables 1 and Chart 1 below).

Table 1: Nigeria's Ranks in Corruption Perceptions Index 1996-2010

\begin{tabular}{|c|c|c|c|c|}
\hline Year & Country rank & CPI Score & surveys used & confidence range \\
\hline 2010 & $134 / 178$ & 2.4 & 7 & $2.2-2.7$ \\
\hline 2009 & $130 / 180$ & 2.5 & 7 & $2.2-2.7$ \\
\hline 2008 & $121 / 180$ & 2.7 & 7 & $2.3-3.0$ \\
\hline 2007 & $147 / 180$ & 2.2 & 8 & $2.0-2.4$ \\
\hline 2001 & $90 / 91$ & 1.0 & 4 & $-0.1-2.0$ \\
\hline 1999 & $98 / 99$ & 1.6 & 5 & $\mathrm{NA}$ \\
\hline 1998 & $81 / 85$ & 1.9 & 5 & $\mathrm{NA}$ \\
\hline 1996 & $54 / 54$ & 0.69 & 4 & $\mathrm{NA}$ \\
\hline
\end{tabular}

Source: Transparency International extracts from 1996 to 2010. 
Chart 1: Tl's Country Corruption Perception Index

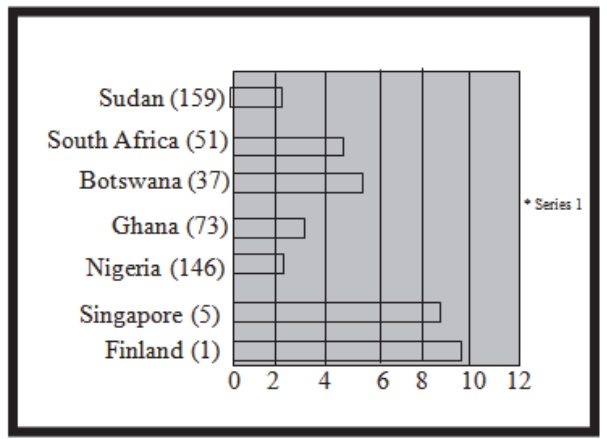

Source: TI, 2010.

Chart 1 above shows that the ranking of some selected countries by their perceived corruption status for the year 2006 extracted from the TI's annual report. Nigeria ranked 146 out of 163 countries with a score of 2.2. The index related the perceptions of the degree of corruption as seen by business people and risk analysts, and ranges between 10 (highly clean) and 0 (highly corrupt). In SSA Nigeria was the most corrupt with the exception of the war turn Sudan. The rank of Nigeria in the TI fluctuates like the price of petroleum in the global oil market. Nigeria ranked 134, 130, 121,147 and 90 in 2010, 2009, 2008, 2007 and 2001 respectively. As governments was committing huge sums to tackle the world's most pressing problems (instability of financial markets, climate change and poverty), corruption remains an obstacle to achieving much needed progress. The 2010 Corruption Perceptions Index showed that nearly three quarter of the 178 countries in the index scored below five, on a scale from 10 (highly clean) to 0 (highly corrupt). These results indicate a serious corruption problem.

To address these challenges, TI advocated stricter implementation of the UN Convention Against Corruption, the only global initiative that provides a framework for putting an end to corruption. Denmark, New Zealand and Singapore were tied at the top of the list with a score of 9.3, followed closely by Finland and Sweden at 9.2. Bringing up the rear is Somalia, Nigeria and most of the SSA countries trailing behind the table

\section{Corruption and Economic Growth}

There appears to be a very high positive correlation between the level of corruption and economic growth. Gould and Amaro-Reynes (1983) Mauro (1997), United Nations (1989), Tanzi and Davoodi (1997) in their separate studies found evidences that bureaucratic malpractice manifests in the diversion of public funds to where bribes are easiest to collect. This implied that there is a bias in the composition of public funds towards low-productivity projects at the expense of value enhancing investments. Again, there is a two-way causal relationship between corruption and economic growth: bureaucratic rent-seeking do not only influence, but it is also influenced by the level of development. Krueger (1993) describes the promotion of rent seeking activities as one form of corruption today. Treisman (2000) observed that rich countries are generally rated as having less corruption than poor countries with as much as 50 to $73 \%$ of variations in corruption indices. This accounted for variations in per capita income levels between the rich and the poor nations. Crosscountry differences in the incidence of corruption owe much to differences in the level of prosperity because corruption provides ways of bypassing regulation.

The link between corruption and economic growth can be gleaned by accessing the impact of corruption on the lives or welfare of the people. Rose-Ackerman (1997) listed several channels through which poor people are hurt by corruption. Firstly, the poor will receive a lower level of social services. Secondly, infrastructure investment will be biased against projects that aid the poor. Thirdly, the poor may face higher tax or fewer services. Fourthly, the poor are disadvantaged in selling scale enterprise. Similarly, Gupta, Daoodi, and Alonso-Terme (1998) identified several channels through which corruption worsens poverty. They include:

- corruption lowers economic growth

- corruption biases the tax system to favor the rich and well-connected

- corruption reduces the effectiveness of targeting of social programs

- corruption biases government policies towards favoring inequality in asset ownership 
- corruption lowers social spending

- corruption reduces access to education by the poor

- corruption increases the risk of investment by the poor

Meanwhile, almost every regime in Nigeria, both military and civilian governments has been accused of one corrupt practice or the other. Meanwhile, in defense of democratic, Sorensen (1993) claimed that authoritarianism leads to arbitrary rule and corruption while democracy promotes accountability and transparency which encourages economic growth and development. Contrary to long-standing arguments that corrupt political regimes do not adversely affect the rate of investment and growth of total income, he denied even known possibility of association between corruption, democracy and development.

Realizing the interconnection between state and economy, votes and money and or wealth and power, Huntington (1968) argues that what matters for economic development is political stability. Similarly, Alesina and Perotti (1997) added that what influences growth is not so much the type of regime whether dictatorship or democracy but regime instability. They argued that democracy is sustained when losers in election accept defeat and winners accommodates loser's interests in decision making. Consequently, Nigeria remains one of the countries at the lower ebb in the Human Development Index in Sub Saharan Africa. Despite the huge human and natural resources in Nigeria, the country ranks $25^{\text {th }}$ in African Human Development Index below Mauritania, Togo Comoros and Lesotho (UNDP Human Development Report, 2010). Nigeria's GDP fell as the general inflow of FDI into Africa is marginal compared with the rest of the regions of the world (IMF, 2010). In 2009, African countries were sorted by their nominal GDP Nigeria was on the decline from 207.116 billion naira in 2008 to 165.437 billion naira in 2009. Generally, the GDP of Africa was 2.5\% of the total GDP of the world in 2008 and declined to 2.3\% 2009. Again, the inflow of FDI into Nigeria was affected by mounting incidence of corruption and political instability recently manifested in the Niger Delta upsurge.

\section{Efforts to Tackle Corruption in Nigeria}

Obviously, corruption is an act propelled by greed. It is often at the expense of another. It exacerbates deprivation and accelerates the scourge of poverty which enriches the few at the expense of the masses. It takes from the poor and gives to the rich. Thus, the abolition of all forms of corrupt practices will certainly pave way for meaningful investments with a view to eliminating poverty.

Corruption thesis ironical explains that Nigeria is the sixth largest producer of oil in the world, yet the country scandalously continues to import fuel to meet its local needs. Public officials flaunt wealth they could never ordinarily acquire. Over the years in Nigeria, misallocation of public resources and stealing of the common wealth have become institutionalized. It is in this respect that President Olusegun Obasanjo came up with numerous activities aimed at fighting corruption such as the Anti-Corruption Act, the Independent Corrupt Practice and Other Related Offences (ICPC) Economic and Financial Crime Commission (EFCC). To boost its efforts in the anti-corruption crusade, the United Nation set aside \$32 million (about N4 billion) for EFCC. Regrettably, these did not reduce the rate of corruption under President Obasanjo between 1999 and 2007. Between 29th May 2007 and 2010, President Yaradua sustained a zero-tolerance to corruption in public affairs. Despite this approach, the incidence of corruption remained identifiable among policy implementers from federal, states and local governments in Nigeria.

We also consider some other indicators that are accepted as yardsticks of measuring the level of economic growth of a country globally and continently. These factors were developed by reputable institutions such as the World Economic Forum (WEF), the Transparency International (TI), Business International (BI), Political Risk Services (PRS), etc. This section presents on analysis using some of the indices developed by these institutions in support to the above empirical analysis. Table 2 below shows Nigeria's competitiveness in SSA. 
Table 2: Competitiveness Indicators of Public indicators in SSA Countries, 2009

\begin{tabular}{|c|c|c|c|c|c|}
\hline Country & SSA Rank & Global Rank & Country & SSA Rank & Global Rank \\
\hline Botswana & 1 & 36 & Botswana & 1 & 26 \\
\hline South Africa & 2 & 42 & Malawi & 2 & 38 \\
\hline Mauritius & 3 & 46 & Gambia & 3 & 39 \\
\hline Namibia & 4 & 52 & South Africa & 4 & 43 \\
\hline Gambia & 5 & 55 & Mauritius & 5 & 44 \\
\hline Tanzania & 6 & 69 & Namibia & 6 & 48 \\
\hline Ghana & 7 & 71 & Tanzania & 7 & 59 \\
\hline Malawi & 8 & 76 & Ghana & 8 & 65 \\
\hline Senegal & 9 & 79 & Zambia & 9 & 69 \\
\hline Uganda & 10 & 80 & Ethiopia & 10 & 73 \\
\hline Kenya & 11 & 83 & Senegal & 11 & 75 \\
\hline Nigeria & 12 & 87 & Mozambique & 12 & 82 \\
\hline Zambia & 13 & 88 & Mali & 13 & 83 \\
\hline Cameroon & 14 & 91 & Uganda & 14 & 84 \\
\hline Ethiopia & 15 & 92 & Zimbabwe & 15 & 90 \\
\hline Mozambique & 16 & 93 & Angola & 16 & 91 \\
\hline Madagascar & 17 & 96 & Kenya & 17 & 92 \\
\hline Zimbabwe & 18 & 97 & Cameroon & 18 & 95 \\
\hline Mali & 19 & 99 & Madagascar & 19 & 98 \\
\hline Angola & 20 & 100 & Nigeria & 20 & 98 \\
\hline Chad & 21 & 101 & Chad & 21 & 101 \\
\hline
\end{tabular}

Source: IMF, 2009.

Table 2 above shows that Nigeria was ranks as the 12th competitive nation in SSA and the $87^{\text {th }}$ in a total of 101 countries on the global ranking for public institutions competitiveness. This is an indication that the macroeconomic and technological environment and the level of development of Nigeria's public institutions are adverse to economic growth and development. Table 2 and Chat 2 below show the level of public expenditure and social and economic services in Nigeria between 1996 and 2006 and the rate of public fund diversion in Nigeria.

Table 2: Level of Expenditure On Social And Economic Services, 1996-2006

\begin{tabular}{|c|c|c|c|c|}
\hline Year & Score: Max. of 10 & Position in Total Survey & Per Capita Income (in Natural Log) & SES (Nb) \\
\hline 1996 & 0.6 & 54,54 & 10.21266 & $23,528.3$ \\
\hline 1997 & 1.8 & 52,52 & 10.22662 & $29,124.6$ \\
\hline 1998 & 1.9 & 81,85 & 10.17421 & $34,639.6$ \\
\hline 1999 & 1.6 & 98,99 & 10.33442 & $58,199.5$ \\
\hline 2000 & 1.2 & 90,90 & 10.65100 & $88,618.7$ \\
\hline 2001 & 1.0 & 90,91 & 10.65100 & $88,618.7$ \\
\hline 2002 & 1.6 & 101,102 & 11.06208 & $255,342.5$ \\
\hline 2003 & 1.4 & 132,133 & 11.27192 & $198,597.7$ \\
\hline 2004 & 1.6 & 144,146 & 11.38312 & $193,172.4$ \\
\hline 2005 & 1.9 & 154,159 & 11.59902 & $215,955.1$ \\
\hline 2006 & 2.2 & 142,163 & 11.72135 & $221,561.2$ \\
\hline
\end{tabular}

Sources: TI and CBN,2006 
Chat 2: Diversion of Public Funds 1997-2009

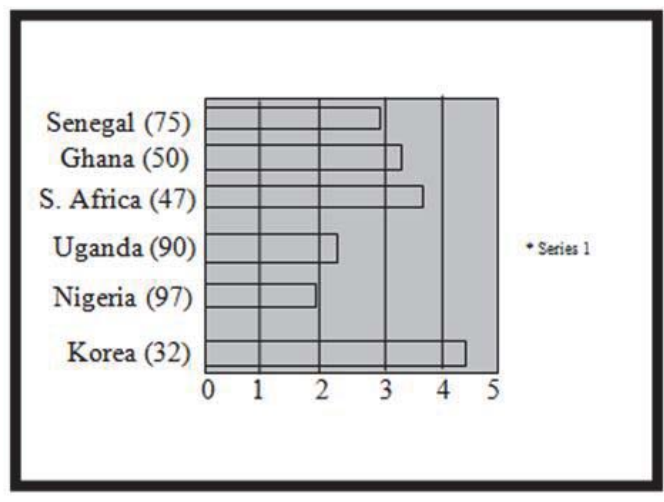

Source: The Africa Competitiveness Report, World Economic Forum, 2010.

Despite that Nigeria scored 0.6 points in the maximum of 10 points in 1996 and increased to 2.2 in 2006, the amount spent on social and economic services have increased but the effect is yet to reflect on the living standard of Nigerians hence poverty rate continues to rise astronomically unlike never before. It is argued that more than 70 per cent of Nigerians live under the poverty line (IMF, 2010)

From the foregoing, Nigeria could not even compete favorably with other Africa countries like Botswana and South Africa in terms of corruption status. Evidence has shown that in other years, Nigeria's position had remained high. In 1996, 1997 and the year 2000 for instance, Nigeria topped the list as the number one most corrupt nation in the world while in the other years from 2001 to 2010 ranked between $2^{\text {nd }}$ and $4^{\text {th }}$ most corrupt. Evidently, corruption pervades and overwhelms every facet of human life in Nigeria. It also cuts across all levels of the government; the federal, states and local governments, and its organs; the executive, legislature and judiciary. Corruption in legislative bodies, for instance, reduces accountability and representation in policymaking. In the Judiciary, it suspends the rule of law and delays justice and in public administration, it reduces the quality of government services and increases budgetary pressure on the government

\section{Conclusion}

There is a positive relationship between political corruption, democracy, and economic growth and development in Nigeria. Although successive political leaderships evolved an anti- corruption strategy to tame the negative effects of corruption, raise the standard of living and improve the global ranking of Nigeria in various economic or political indices, the most committed to this end was President Obasanjo between 1999 and 2007. Despite this commitment of President Obasanjo between this period, the extent of corruption exemplified by diversion of public fund in Nigeria was most alarming under his administration. Hence, in 2006, the country had the worst record of diversion of public fund for personal gains. The incidence of corruption remains the major enemy of inflow of FDI in Nigeria as the global owners of capital consider the economy as unsafe for investment in the hands of corrupt political leaders. This corrupt leadership syndrome has been sustained since 1960 by massive rigging during general elections, thus, the record of electoral malpractices and fraud that characterize the 1999, 2003 and 2007 elections in Nigeria. Until the masses increasingly participate to decide who/ who do not occupy political offices, economic growth and development will continue to elude Nigerians.

\section{References}

Alesina, A. and R. Perotti, (1997). "The Politics of Growth: A Survey", in V. Bergstrom (ed.) Government and Growth, Oxford: Oxford University Press.

Chuta S.C. (2004). Corruption in Nigeria. Nsukka: Afro.-Orbis Publications Ltd.

Crowther, M. (1962). The Story of Nigeria. London: Faber and Faber.

Ekekwe, E (1986) Class and State in Nigeria. Lagos: Longman.

El-Rufa'i, N. (2003). "Is Liberal Democracy encouraging Corruption and Corrupt Practices? The Privatization Process in Nigeria", Social Science Academy of Nigeria (SSAN), 6 (2): 1-15 
Farnsworth, M. (2002). "Liberal Democracy", retrieved from www.australianpolitics.com on 20th November 2009.

Gould, D.J. and J.A. Amaro-Reynes (1983). "The Effects of Corruption on Administrative Performance", World Bank Staff Working Paper No. 580.

Gupta, Sanjeev, Hamid Davoodi, and Rosa Alonso-Terme (1998) "Does Corruption Affect Income Inequality and Poverty?", IMF Working Paper, May.

Huntington, S.P. (1986). Political Order in Changing Societies. New Haven: Yale University Press,.

International Crisis Group (ICG) (2006). "Nigeria Want in the midst of Plenty", African Report, 113, July 19.

Krueger, A.O. (1993) "Virtuous and Vicious Cycles in Economic Development", American Economic Review, 83 (2): $351-355$.

Mauro, P. (1997). "The Effects of Corruption on Growth, Investment and Government Expenditure: A Cross-country Analysis" in K.A. Elliott (ed.), Corruption and the Global Economy. Washington D.C: Institute for International Economics.

National Population Commission Report (2006)

Ofoegbu, G.A.I. (1999). Modern Government for Senior Secondary Schools in West Africa. Onitsha: Mass Founder Publications Ltd).

Rose-Ackerman, Susan, (1998a). "Bribes and Gifts," in Avner Ben-Ner and Louis Putterman, (eds.) Economics, Values, and organization, Cambridge: University Press.

Sorensen, G. (1993). Democracy and Democratization, London: West view Press.

Tanzi, Vito, and Hamid Davoodi (1997). "Corruption, Public Investment, and growth," IMF Working Paper $97 / 139$.

Treisman, D. (2000). "The Causes of Corruption: A Cross-national Study", Journal of Public Economics, 76: 399-457.

United Nations (1989). Corruption in Government, New York: United Nations. 